\title{
Gamifire - A Cloud-Based Infrastructure for Deep Gamification of MOOC
}

Citation for published version (APA):

Klemke, R., Antonaci, A., \& Limbu, B. H. (2019). Gamifire - A Cloud-Based Infrastructure for Deep Gamification of MOOC. In M. Scheffel, J. Broisin, V. Pammer-Schindler, A. loannou, \& J. Schneider (Eds.), Transforming Learning with Meaningful Technologies: 14th European Conference on Technology Enhanced Learning, EC-TEL 2019, Delft, The Netherlands, September 16-19, 2019, Proceedings (pp. 613-616). Springer. Lecture Notes in Computer Science Vol. 11722 https://doi.org/10.1007/978-3-030-29736-7_51

\section{DOI:}

10.1007/978-3-030-29736-7_51

Document status and date:

Published: 09/09/2019

Document Version:

Early version, also known as pre-print

Please check the document version of this publication:

- A submitted manuscript is the version of the article upon submission and before peer-review. There can be important differences between the submitted version and the official published version of record. People interested in the research are advised to contact the author for the final version of the publication, or visit the DOI to the publisher's website.

- The final author version and the galley proof are versions of the publication after peer review.

- The final published version features the final layout of the paper including the volume, issue and page numbers.

Link to publication

\section{General rights}

Copyright and moral rights for the publications made accessible in the public portal are retained by the authors and/or other copyright owners and it is a condition of accessing publications that users recognise and abide by the legal requirements associated with these rights.

- Users may download and print one copy of any publication from the public portal for the purpose of private study or research.

- You may not further distribute the material or use it for any profit-making activity or commercial gain

- You may freely distribute the URL identifying the publication in the public portal.

If the publication is distributed under the terms of Article 25fa of the Dutch Copyright Act, indicated by the "Taverne" license above, please follow below link for the End User Agreement:

https://www.ou.nl/taverne-agreement

Take down policy

If you believe that this document breaches copyright please contact us at:

pure-support@ou.nl

providing details and we will investigate your claim.

Downloaded from https://research.ou.nl/ on date: 26 Apr. 2023 


\title{
Gamifire - A cloud-based Infrastructure for Deep Gamification of MOOC
}

\author{
Roland Klemke ${ }^{1,2}$, Alessandra Antonaci ${ }^{1}$, and Bibeg Limbu ${ }^{1}$ \\ 1 Open University of the Netherlands firstname.lastname@ou.nl \\ 2 Cologne Game Lab, TH Köln
}

\begin{abstract}
Gamification aims at addressing problems of MOOC (high dropouts, low success rates, lack of engagement, isolation, lack of individualization). We define our understanding of deep gamification and present the Gamifire infrastructure. We also point out planned development activities on this platform.
\end{abstract}

Keywords: Gamifire $\cdot$ Gamification $\cdot$ Architecture $\cdot$ Scalability $\cdot$ MOOC · Platform Independence · Infrastructure

\section{Introduction}

The success of MOOCs comes with downsides: high-drop out rates [3] and low engagement [5]. Gamification was initially introduced to improve situations of motivational gaps by applying elements of gaming into otherwise boring activities [4]. Relying mostly on game elements fostering extrinsic motivational factors (such as points, badges, and levels), mainly in a way that is not even challenging for those who need to be extrinsically motivated, gamification as seen so far does not exploit the true potential of human motivation and passion for learning [6]. Also, many approaches towards gamification fail due to the lack of a clear design methodology [8]. However, deep gamification as the thoughtful integration of gamification with the learning processes can be beneficial to learners [7]. We have developed a methodology for the gamification of MOOCs [2] backed up by a technological solution that aims to reliably support the process. In this article, we highlight the technical side of this research. The following research questions (Q) are investigated in this work: (q1) Can we develop a platform-independent, scalable deep gamification platform for the gamification of MOOC? (q2) Can we resolve the conflict between platform-independence and the required platform integration for deep gamification?

To answer the research questions and to base Gamifire on solid methodological grounds, our methodology comprises three main perspectives: (1) A design perspective, combining game design with problem-based selection of theories into an evaluation-based continuous improvement cycle. (2) A user-experience and usability perspective, taking the interplay of learning environment and gamification into account. (3) A software-engineering perspective, transforming outcomes of the other two perspectives into implementable requirements and architectural 
specifications. Approaches towards gamification design frameworks have been extensively discussed in [8]. Our own approaches towards a methodologically sound gamification design and towards user-experience evaluation have been reported in $[2,1]$, respectively. This article takes the software-engineering perspective and reports the corresponding process steps and results.

\section{Gamifire - Architecture and Implementation}

Gamifire is implemented on top of the Google App Engine (GAE) cloud platform. Gamifire uses a three-tier architecture, with database back-end (cloud data-store), an application server, and front-end user-interface (UI) components. The back-end stores logging information collecting data about user interactions, time-stamps, and progress related data. Each game element/widget can also store widget specific data. The application server handles user related sessions, tracks user interactions, manages logging operations and generates feedback and UI-related content. To generate the UI, Gamifire relies on a library of game element widgets, which are triggered by the main application logic and which provide the individualized view on the game elements with respect to the user status. These UI elements are embedded into the MOOC platform by frontend integration, which means, they are added to the web-based front-end of the MOOC platform as partial HTML components. Through JavaScript introspection, these front-end elements gather user information from the MOOC platform and can thus synchronize user sessions and data between MOOC and Gamifire. Fig. 1 shows the general Gamifire component architecture and its integration into an (abstract) MOOC platform. Fig. 2 shows the user interface components displaying different game elements and components.

\section{Conclusions and Future Work}

With the implementation of Gamifire, we were able to show that it is possible to deliver a "scalable, platform-independent, cloud-based Infrastructure for deep gamification of MOOC". However, the implementation and application of Gamifire faces a number of trade-offs, which show, that some conceptual issues have to be addressed in future work: (1) The trade-off between platform-independence and deep gamification requires to be re-thought, in order to get rid of erroneous extra work. (2) The conflicts between some of the game elements requires us to offer more guidance to designers of MOOCs and gamification. To achieve this, more research on the effects of specific game element configurations needs to be performed. Overall, gamification remains a process requiring well-defined procedures and thought through concepts and implementations. With the development of Gamifire based on the methodology presented we contribute to a better understanding and applicability of deep gamification in the context of online learning. 
Fig. 1: Architecture of the Gamifire platform

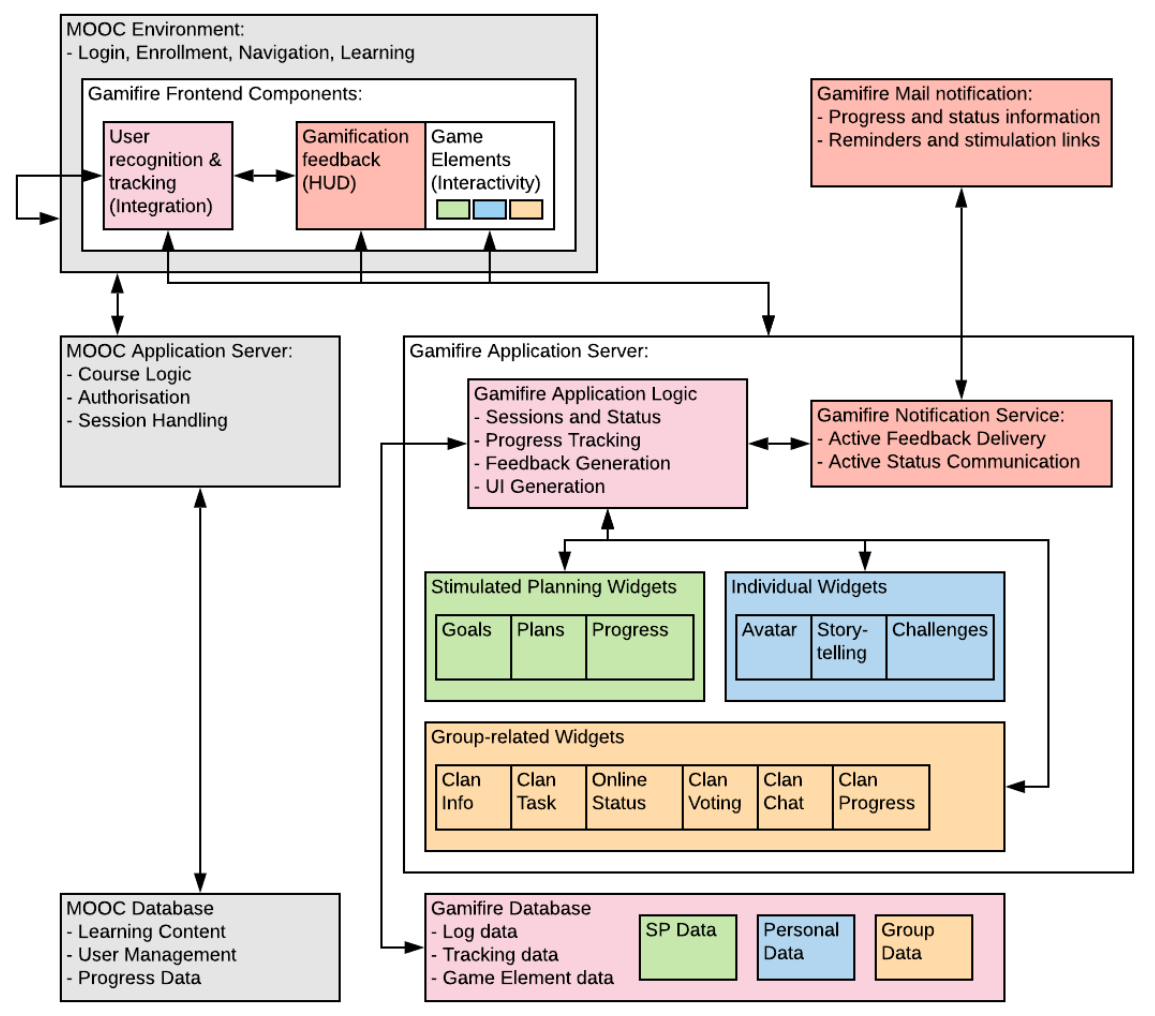

\section{References}

1. Antonaci, A., Klemke, R., Dirkx, K., Specht, M.: May the Plan be with you! A Usability Study of the Stimulated Planning Game Element Embedded in a MOOC Platform. International Journal of Serious Games 6(1) (2019), http://journal.seriousgamessociety.org/index.php/IJSG/article/view/239

2. Antonaci, A., Klemke, R., Kreijns, K., Specht, M.: Get Gamification of MOOC right! How to Embed the Individual and Social Aspects of MOOCs in Gamification Design. International Journal of Serious Games 5(3) (2018). https://doi.org/10.17083/ijsg.v5i3.255, http://dx.doi.org/10.17083/ijsg.v5i3.255

3. Atiaja, L., Proenza, R.: The MOOCs: origin, characterization, principal problems and challenges in Higher Education. Journal of e-Learning and Knowledge Society 12(1) (2016)

4. Deterding, S.: Gamification: designing for motivation. Interactions 19(4), 14-17 (2012)

5. Dillon, J., Bosch, N., Chetlur, M., Wanigasekara, N., Ambrose, G., Sengupta, B., D'Mello, S.: Student Emotion, Co-Occurrence, and Dropout in a MOOC Context. Educational Data Mining (2016) 


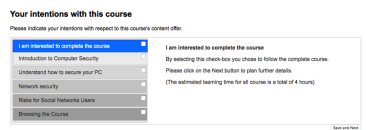

(a) SP: Intentions

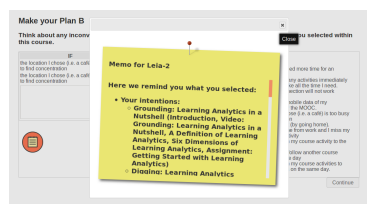

(d) SP: Memo

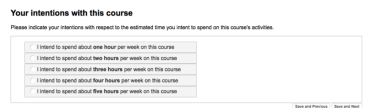

(b) SP: Intentions

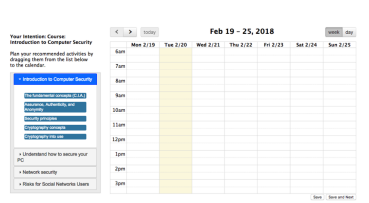

(e) SP: Planning

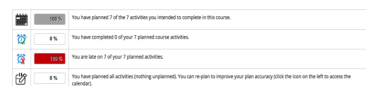

(c) HUD: Feedback

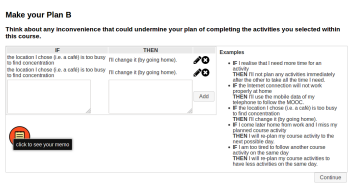

(f) SP: Plan B

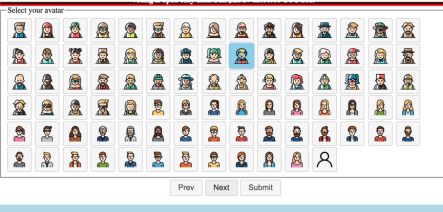

(g) Avatar

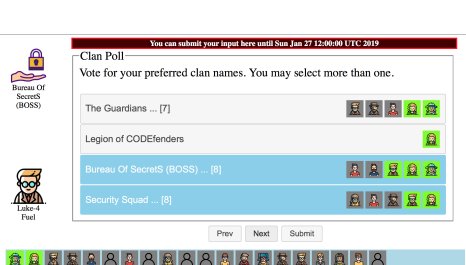

(i) Clan voting

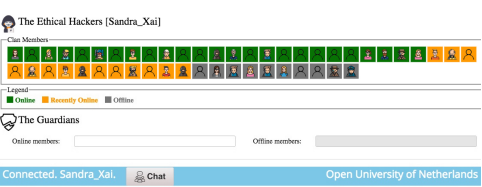

(h) HUD: Online status

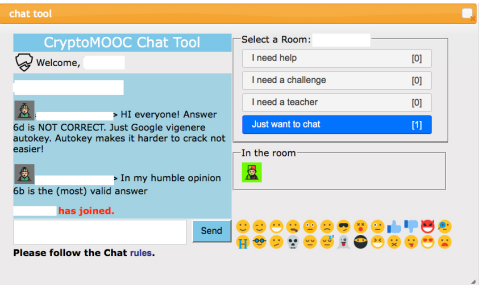

(j) Clan chat

Fig. 2: Screen-shots of Gamifire UI components.

6. Hamari, J., Koivisto, J., Sarsa, H.: Does Gamification Work?-A Literature Review of Empirical Studies on Gamification. HICSS 14, 3025-3034 (2014)

7. de Marcos, L., Garcia-Lopez, E., Garcia-Cabot, A.: On the effectiveness of game-like and social approaches in learning: Comparing educational gaming, gamification \& social networking. Computers \& Education 95, 99-113 (2016)

8. Mora, A., Riera, D., Gonzalez, C., Arnedo-Moreno, J.: A Literature Review of Gamification Design Frameworks. In: VS-Games 2015 - 7th International Conference on Games and Virtual Worlds for Serious Applications. IEEE (2015) 